International Journal of English Literature and Social Sciences
Vol-6, Issue-2; Mar-Apr, 2021
Journal Home Page Available: https://ijels.com/
Journal DOI: $10.22161 /$ ijels

\title{
Rebellion in the Poems of Kazi Nazrul Islam: A Misconception of General Branding
}

\author{
Rashed Mahmud ${ }^{1}$, Joshimuddin ${ }^{2}$
}

${ }^{1}$ Assistant Professor, Department of English, Pabna University of Science and Technology, Pabna- 6600, Bangladesh
${ }^{2}$ Lecturer of English, Sylhet Cantonment Public School and College, Sylhet- 3103, Bangladesh

Received: 03 Jan 2021; Received in revised form: 05 Mar 2021; Accepted: 01 Apr 2021; Available online: 19 Apr 2021 C2021 The Author(s). Published by Infogain Publication. This is an open access article under the CC BY license (https://creativecommons.org/licenses/by/4.0/).

\begin{abstract}
Kazi Nazrul Islam, a multifaceted genius, is widely acknowledged as the epoch-making rebel poet for his significant and distinctive contributions to the awakening and rejuvenation of the masses in this part of the world. He hurled his fire throwing shells of poetry as revolt against the British Raj in India and preached revolution. Even though Nazrul is recognized as the rebel poet, his writings also explored themes like love, freedom, revolution, humanism, nationalism, equality, justice, etc. Besides, he very effectively contributed to almost every genre of literature and covered almost every sphere of human life. Hence, it is a misconception about him that he is only a rebel poet. To think in this single way is very partial in terms of assessing him and his literary works. In his works, he protested against all forms of oppression, sang of equality, unity, fraternity and struggled to establish peace and harmony. The paper, through proper justification of the major themes of his works, aims at exploring the misconceptions about generalizing Nazrul as a rebel poet and tries to show that he is not only a rebel poet but also a poet of other aspects.
\end{abstract}

Keywords_rebellion, humanism, egalitarianism, feminism, romanticism, patriotism, fraternity.

\section{INTRODUCTION}

Kazi Nazrul Islam (1899-1976) was a Bengali poet, musician, revolutionist and philosopher who produced poetic works advocating intense spiritual rebellion against orthodoxy and oppression. As a multifaceted genius, he introduced new styles in Bengali literary writing and tried to free Bangla literature, especially poetry, from its stultifying medieval form. Nazrul's poetry and nationalist activism earned him the popular title "Rebel Poet". In Bangladesh, he is officially acknowledged as the national poet. He hurled his fire throwing shells of poetry as protests against the British Raj in India and preached revolution through his poetic works, such as "Bidrohi" (The Rebel), "Bhangar Gan" (The Song of Destruction), and his publication Dhumketu (The Comet). The British Raj was enraged at his activities and imprisoned him for his earnest and passionate involvement in the Indian independence movement. Nazrul's revolutionary activities did not stop in the prison and there he wrote "Rajbandir Jabanbandi" (Deposition of a Political Prisoner). In his writings, he explored the life and conditions of the downtrodden masses of the undivided Bengal and worked for their emancipation. He understood very well that without armed revolt and organizing the proletariats for self rule, it was impossible to attain freedom. Therefore, Nazrul made a clarion call to the youth of Bengal to fight for liberty till the last and thereby build up a society free from oppression and exploitation.

\section{DISCUSSION}

"Bidrohi" (The Rebel): An Indication of the Spirit of Rebellion

Nazrul reached the peak of reputation with the publication of "Bidrohi" (The Rebel) in 1922. "The Rebel", is an epical poem of heroic sentiments that made him the hero of the Bengali people overnight. In outstandingly robust language, Nazrul urged upon every Indian in general and every Bengali in particular to challenge the mighty British rule with great courage (Abbasi 67). The poem is his most 
renowned work that won admiration of India's literati by his portrayal of the rebel whose impact is fierce and ruthless even as its spirit is high. He utters in "The Rebel":

I'm the tempest I'm the cyclone,

I destroy everything I find in my path

I'm the dance-loving rhythm

I dance to my own beats. (35-38)

Nazrul imagines himself as the cyclone, the symbol of destruction; he can destroy everything that comes in his path. He shows an amalgamation of different forces in a rebel who is a destroyer and a preserver, and who expresses wrath as well as beauty and sensitivity. Through the poem, Nazrul celebrates human creative powers, asserts his affirmation of the individual human capacity for heroic action and human unity, and solemnly calls for rebellion against all forms of oppression including that of the British in India, and all these elevate him to the status of a national figure (Langley 12).

In the poem, Nazrul utters: "Proclaim: I raise my head high! / Before me bows down the Himalayan peaks" (2-3). He calls upon everyone not to suffer from any sense of inferiority and raise their heads as high as Himalayan peaks, to meet the challenge of time. Nazrul shows his revolutionary zeal through his voice. He says:

I'm ever indomitable, arrogant and cruel.

I'm the Dance king of the Day of the Doom

I'm the cyclone, the destruction!

I'm the great terror, I'm the curse of the world. (17-20)

Nazrul reveals his indomitable spirit to demolish all the barriers of the downtrodden society. He writes that "I'm the Rebel, the Rebel son / of creator of the universe!" (3132) He declares that he has been created by the creator of the universe. Nazrul's rebellion is more comprehensive, more wide ranging and more instructive for the human beings. Many critics compare Nazrul with Shelley. While Shelley's "Ode to the West Wind" invokes all the optimistic norms and values, Nazrul invokes all the revolutionaries' zeal through his poem.

The readers find several examples of Nazrul's dreams to create a beautiful world through his poems. Nazrul says:

I'm the Sacrifice, I'm the priest.

I'm the fire itself.

I'm creation, I'm destruction. (57-59)

Nazrul proclaims himself as a destroyer as well as creator. He also treats himself as a messenger of revolt. He says,
"I'm the messenger of revolt / across the earth and the sky." (150-151) Nazrul, in "The Rebel" is modern Prometheus; he is the "Great upheaval", the destroyer who will "rest in peace only when / the anguished cry of the oppressed" (179-180), the enslaved, and the degraded "shall no longer reverberate in the sky and the air, / and the tyrant's bloody sword / will no longer rattle in battlefields" (181-183). This Prometheus is also the blazing comet who is the enemy of all creation, the revolutionary who defies God and achieves "what the hollow stuffed God" could not achieve; he is also the rebel who, in triumph, arrives at the gate of a liberated world ready to begin the creation of the human common wealth.

With the publication of this poem, Nazrul was given the glory of becoming the Rebel Poet of Bengal. He is the only Bidrohi Kobi or the Rebel Poet of Bangla language. The fag end of Nazrul's life saw decolonization process involving violence at many places. The non violent character of Indian independence movement under the leadership of Mahatma Ghandhi was put to a secondary position after the massacre of Jalianwalabag where 344 unarmed people were brutally murdered along with active steam roller of activities leading to suppression and constant violations of human rights by the occupants (Abbasi 287). People were revolting to end the political oppression and the revolutionary thoughts were organized to establish the communist party in India with the hope of eliminating the exploitation of working people. Muzaffar Ahmed, one of the founders of the communist party in India, writes in his memoirs that by the end of 1921 when they were trying to form the party, Nazrul was also with them. Nazrul responded to the revolutionary tendencies most sensitively. "The Rebel" after which he is known as the Rebel Poet, was the product of his poetic response to the call of the age, the most outstanding poetic creation of his life. The superb brilliance of the poem "The Rebel" has always been acknowledged by all. It not only reflected the spirit of the age, but also, as the critics think, showed the golden way of Nazrul's self-expression (Goswami 36).

\section{A Short Glimpse over Nazrul's Revolutionary Spirit}

Obtaining the title of the "Rebel Poet", Nazrul roused the suspicion of British authorities. In 1922, he published "Anondomoyeer Agomone" (On the Arrival of the Goddess of Delight) where he urged the devotees to fulfill Puja's real spirit by sacrificing blood in an armed struggle for freedom. As the poem was political in spirit, it instigated the British authorities to conduct a raid on the office of Dhumketu. Consequently, Nazrul was arrested and charged with sedition. In the court, he presented a long argument namely "Rajbandir Jabanbandi" (Deposition of a Political Prisoner) where he says: 
The charge against me: I'm a rebel against the Crown. Therefore, I'm now a prisoner, convicted by a royal court. On one side is the Royal Crown, on the other, the flame of the Comet. One is a king, with a scepter in his hand; the other is the Truth, with the scepter of Justice. On the side of the king are state-paid government employees. On my side is the King of all kings, the Judge of all judges, the eternal Truth - the awakened God." (Islam 211-212)

In spite of being imprisoned and tortured by the occupational forces, Nazrul continues his rebellious writings and shows his indomitable spirit to fight against injustice to establish the truth. He further says:

I'm a poet, sent by God to speak the unspoken Truth, to give form to the formless creation. God speaks through the voice of the poet. The message is the revelation of the Truth, the message of God. That message may be judged seditious in a state-court, but in the court of Justice, that message is not against Justice, not against Truth. That message may be punishable in a state-court, but in the light of Religion, at the door of Justice, it is innocent, untainted, untarnished, inextinguishable as the Truth itself. (Islam 211-212)

The statement shows how courageous Nazrul was and how greatly he could risk his personal security when the question of the country came up.

In jail, Nazrul began a forty-day fast to protest illtreatment by the British jail superintendent. While in jail, Nazrul wrote numerous poems and songs. In 1924, he published Bisher Banshi (The Flute of Poison) which was banned by the British Raj. The book ignited rebellion in India against the British rule.

However, 1921 was a tumultuous year for India. Political agitations under the impact of Khilafat and nonco-operation movements were reaching newer heights. Political agitations began to be stronger and more organized day by day. The Congress spirit of non-violence was gradually losing ground and people began to favour violent agitations against the British Raj. In the last quarter of the year the British authorities began to take very harsh measures to suppress the agitations. They began to put the political leaders behind the bars and perpetrate coercion on the agitating people who, in a very large number, were being arrested (Goswami 32).
These were the political situations that Nazrul had to face as he returned to Calcutta from Comilla. Deshabandhu Chittaranjan Das was arrested on December 10, 1921 leaving his weekly, Banglar Katha (Voice of Bangla) in charge of his wife Basanti Devi. Basanti Devi, who had a deep admiration for Nazrul for his revolutionary and patriotic spirit, sent him a request to contribute to the weekly. Nazrul who was himself an admirer of Chittaranjan was glad to receive the offer and wrote a song which has immortalized him in the history of Bengali patriotic poetry (Goswami 32). Nazrul called it "Bhangar Gaan" or "The Song of Destruction". Nazrul's heroic sentiment reached a new height in this composition. The first stanza of the song is as follows:

Break down the iron gate of prison

And break down into pieces

The blood-bathed

Stone-altar of the goddess of fetters. (qtd. in Goswami 33)

"The Song of Destruction" is the first great patriotic song of Nazrul. It depicted the spirit of the violent age and marked the beginning of filling up the emptiness which had then been persisting in the trend of Bengali patriotic songs. Gopal Haldar, a celebrated Bengali author, has described it as the first great song of the national movement. He says:

It was the first great song of the national movement, something more strident than the swadeshi songs of the old and one which was a fore-runner of some more songs that Nazrul was to offer in the days to come. As a call to action, in its tune and wording and general appeal the song was of unfailing effect. (qtd. in Goswami 33)

Kazi Nazrul Islam was a great socio-political personality. Since his arrival in Calcutta from Karachi he began to work in the social-political front with a deep sense of dedication. He was not still a regular member of any political party. So far as his attitude to struggle for liberty was concerned, he was in favour of complete independence of India. He made this attitude known in unequivocal terms in an editorial in his 131-weekly The Comet. Nazrul's spirit of struggle resembles the spirit of the secret revolutionary freedom fighters who did not hesitate to sacrifice their own lives for the sake of compelling the British to leave India.

From the very first issue, The Comet earned exceptional popularity. Its mutinous attitude and openminded evaluation of the contemporary problems which 
aggravated the socio-political atmosphere stirred the mind of the people of Bengal. Gopal Haldar has wonderfully described the popularity of The Comet. He says that the people of Bengal, particularly the youths, went wild over every issue of The Comet. The people of Bengal, especially the youths, went wild over every issue of it. Every number of it was paid for in advance and naturally each evening was celebrated, especially on the day the paper came off the press, at the typical Bengali adda (informal gathering) at The Comet's office. The essays Nazrul wrote and published in The Comet clarify his attitudes to the socio-political problems of the day (Goswami 42).

Nazrul represented the revolutionary spirit of his times in many other poems. He voiced against the evil thoughts of the contemporary society in "Coolies and Laborers". In the poem, he sympathizes with the suppressed humanity by asking "Should the weak - the world over - go on / getting beaten like this?" (4-5) He further says:

Shut-up, You liars! How many millions

Have you amassed-with pittance to the coolies?

The cars, the ships, that trains, the factories

Whose gifts are this? (11-14)

In "Manush" (Human Being), Nazrul explored the hypocrisy of the religious personalities who regard scriptures as superior to humans. They spoil time injecting holy books and scriptures into their brain while God's best creation suffers. Nazrul calls upon the great personalities from history to change the situation. He writes, "Where are you Chengis, Ghazni Mahmood, Kalapahar? / Smash the locked doors of these houses of worship" (46-47). Nazrul shows his revolutionary zeal through his poem "Amar Kaifiyat" (My Answer) too. He says-

Even the Non-violent and Noncooperation parties

are not happy with me.

I'm supposedly a "violin of violence." (51-55)

The readers find Nazrul as a "violin of violence" in the society. He plays his violin against all forms of oppression to build up a society free from the agonized cry of the oppressed, a society where people would live harmoniously irrespective of class, caste, creed and religion, and where Muslims and Hindus would bear no hostility to one another.

\section{Misconception of General Branding}

It is very transparent to all that Nazrul is the most versatile genius of the century who wrote in almost all the literary genres. He is not only a rebel poet but also a poet of other aspects. Rebel though he was, his area of interest was not confined to heroic sentiment alone; he was also a poet of love. Because no poet can ever become a rebel without love- love for the beloved and dear ones, love for the homeland, love for fellow citizens and love for the humanity as a whole. Love is the main driving force that took Nazrul to the path of revolt (Rahman). And both his rebellion and love issued from the same source, namely, youthfulness. He stood as a symbol of youthful vigour which had its amazing expression of romantic love in poems and songs of distinctive form and diction (Abbasi 67). Nazrul's writings explore themes such as love, freedom, revolution, humanism, nationalism, equality, justice, and so on. It is a misconception about him that he is only a rebel poet. To think in this single way is very partial in terms of assessing him and his literary works. Though he is best-known as a poet, he wrote short stories, novels, plays and essays too. It can be proved through proper justification of the major themes of his works that Nazrul is not only a rebel poet but also a poet of other aspects.

\section{Major Themes of His Poetry}

Major themes of Nazrul's works are humanism, egalitarianism, feminism, patriotism, nationalism, multiculturalism, globalism, romanticism, mysticism, exploration of religion, post-modernism, the environment, human nature as well as human capacities. The "theme of human unity- as opposed to the 'clash of civilizations'- is therefore one of his preoccupation. True human unity is not some artificial accretion to human evolution; it is, rather, the organic and natural flowering of a common rooting; it is the sought-after spiritual, political, and social culmination of an ever present human yearning" (Langley 14). Nazrul advocated both polyculturalism and multiculturalism (15). Multiculturalism is the world view, which says that people should open themselves and help others to open up to the wider collective inventory of meaning within and outside a given society. Multiculturalism, as Langley notes, usually places individual within one of many separate cultural communities (15). Nazrul understood that speaking of or describing human unity is not enough, if human liberation from culturally constructed walls such as gender, class, race, religion, ethnicity, nationality, and social origin, among others, is to be realized (15). For this reason, he supported polyculturalism and multiculturalism. 


\section{Humanism}

Nazrul was an exponent of humanism (Moniruzzaman 153-54). His writings produce the pulse beat of the common humanity. He aims at seeing all humans on earth happy and free from all forms of bondage. He believed, as it should be, in the brotherhood of humankind. But the world is conflict-torn; barbaric war and bloodshed prevail everywhere. In the British ruled India, the major religious communities were on conflicts. Nazrul, as the noble representative of fraternity and true guide for all, deplored inhuman communal riots and wrote with equal love for all classes of people upholding human dignity. He regarded humans above everything else and placed them above all creatures on earth. In "Human Being", he declares:

\section{I sing of equality}

There is nothing greater than a human being

Nothing nobler! (1-3)

This is reminiscent of the fifteenth-century Vaisnava poet Chandidas who said, "Hear, ye man, my brother - / Man is the Truth above everything else / There is nothing above that" (qtd. in Mitra 69). Nazrul considers humans above everything else and offers all his love, respect and devotion to humankind. His aspiration for human superiority is so high that he feels the presence of God in humankind. He writes in his poem "God":

You search for the creator
Instead of searching for your self.

O self-inflicted Blind - open your eyes, Look at yourself in the mirror.

You'll see - His shadow falls on your body. (14-18)

Nazrul also vehemently criticizes the hypocrites who consider scriptures as superior to human beings. They waste their time searching for God in scriptures while His best creation suffers. Nazrul tells them, "Listen you ignorant: Human beings / have brought the books, / the book never brought human beings! (Human Being" 59-61)

To Nazrul, all humans are innocent and free from impurities. He gives the eternal message that even after birth, all the humans are innocent and free from impurities. Even the prostitutes, who are ostracized from society, are also innocent. A prostitute may commit a sin, but it does not mean that she has no right to return to virtue. In 'Barangana' (Prostitute), Nazrul says, 'Listen to this Message of humanity / After birth, all human beings / are free of all impurities" (35-37).
Nazrul also did never believe in the distinction between human beings on the perception based on different faiths. That is why, his poems and songs speak of humanity. He writes in his poem "Samyabadi" (I Sing of Equality): "What I've heard, my friend is not a lie / there's no temple or ka'aba / greater than this heart! (48-50) According to Nazrul, human heart is the greatest ka'aba or temple in the world. All humans are equal irrespective of class, caste, creed and religion. So, Nazrul sings the triumph of humanity. In "The Rebel", he declares, "I am the flag of triumph at the gate / of the universe / the triumph of humanity! (134-136). Nazrul, as a rebel, sings the triumph of humanity. Through his rebellious poems and songs, he fights against the oppressive rulers vehemently and professes humanism against all forms of tyranny and misrule.

\section{Sense of Equality}

Nazrul is also best-known as the poet of equality. He not only hated inequality but also held his fiery pen against it. In many of his poems, he focuses on breaking inequalities and urges people to be united and live peacefully. In his poem "Proclamation", he calls people to "come forward, holding hands with each other" (1). He tells them to get lesson from idealized Muslim figures like Omar, Hossain and Khalid, "to shatter into pieces / all inequalities" (7-8). In "Coolies and Laborers", he urges all people to "stand on the shore and listen / to the flute-call of unity" (52-53). In his eyes, men and women have no differences. In "Nari" (Woman), he says:

I don't see any difference

Between a man and woman

Whatever great or benevolent achievements

That are in this world

Half of that was by woman

The other half by man. (2-7)

Nazrul stunned the society with his poem "Prostitute" in which he addresses a prostitute as "mother". He recognizes the prostitute as a human being. He argues that the person (prostitute) was perhaps breastfed by a noble woman who belongs to the race of "Mothers and Sisters". To him, the prostitute must receive respect as a fellow human being. Nazrul utters, "Who calls you a prostitute, mother? / Who spits at you? / Perhaps you were suckled by someone / as chaste as Seeta" (1-4).

Nazrul believes in the equality and fraternity of human race. He treats the sense of equality in his poem "I Sing of Equality". He says, "I sing of equality / in which dissolves / all the barriers and estrangements / in which are 
united / Hindus, Buddhists, Muslims, Christians. / I sing of equality" (1-6). As Nazrul's life-long quest was to see his countrymen and people of the world united living harmoniously and peacefully, he preached this sense of equality everywhere. In his last speech titled "If the Flute Doesn't Play Any More", delivered at Calcutta Muslim Institute in 1941, he proclaims:

The constant fighting between Hindus and Muslims, animosity between nations, and wars; the inequality between the mercilessly poor, indebted and needy and the monstrously greedy piling up crores and crores of rupees in banks - these are what I came to eliminate. In my poetry, songs, music, works, I have established the beauteous unity and equality. (Islam 223)

The above lines clarify Nazrul's stand on establishing equalities in the society. To live a happy, peaceful and harmonious life, every human being should receive equal treatment from the society and/or the state. Therefore, Nazrul urges people to establish unity and equality through his writings.

\section{Feminism}

Feminism is a relatively modern term that denotes the belief that women should enjoy the similar rights and opportunities as men. It is a train of socio-political movements and ideologies that point at a common aim: to identify, establish, and attain equal personal, social, economic, political, rights for women (Hawkesworth 2527). Though feminist awareness emerged in the nineteenth century, it took the shape of a movement in the twentieth century. Nazrul, however, did not write anything as part of feminist movement though, but feminist awareness abounds in his writings.

Nazrul is credited for his sincere attempt to change people's perception of women. His writings helped both men and women change their minds about the role of women. On the one hand, he convinced men to think outside the box and, on the other, influenced women to explore their minds to perform diverse roles in society. His vision of gender equality was nicely expressed in his poem "Woman". In fact, "Woman" is the most effective poem to establish equality between men and women's rights. When Nazrul utters that "I don't see any difference / between a man and woman" (2-3) and whatever great or benevolent achievements have been attained in this world, "Half of that was by woman / The other half by man" (6-7), he shows his proper respect to women. He even opines that every woman should be given proper respect even if she is a prostitute. As nobody is born as a sinner or killer, very much in the same way no woman is born as prostitute. So, in his poem "Prostitute", he honours prostitutes calling "mothers and sisters" who were perhaps suckled by someone as chaste as "Seeta".

However, Nazrul not only upholds women's status and glorifies their roles, he becomes optimistic of the empowerment of women. In "Woman", he proclaims, "That day is not far off / When the world shall sing the glory of woman / along with that of man!" (136-38) As an advocate of the emancipation and empowerment of women, Nazrul foretold that one day women will get their rightful position in the society. That day the society will also sing the triumph of women along with that of men. Indeed, nearly a century has passed since Nazrul wrote these lines; and today, in every sphere of life, the society is singing the glory of women.

\section{Romanticism}

Nazrul is called a Romantic poet. Romanticism, as one of its most distinctive features, has always fiercely espoused and defended the individual and his freedom (Langley 74). And all through his writings, Nazrul tried to promote individual freedom, humanism, egalitarianism and free his countrymen from the oppressive rule. In his "Agnibina" (The Burning Lute), there are elements of romanticism, heroism, mysticism, revolt and love. In the compilation, he tried to establish the "invincible power of human creativity, strength of the individual for heroic encounter with personal integrity and solidarity with fellow human beings, in defiance of evil forces" (Rahman). As a 'romantic rebel', Nazrul sought to shatter all oppressive and imposed rules and usher in reformations in the existing set-up. He was able to bring out some reformations by raising his voice against all forms of oppression and injustices (Talukder). Like the romantic poets Shelley and Byron, Nazrul dreamt of building up a society that is free of prejudicial beliefs.

There are many fragments of romanticism in Nazrul's poems. His "Hope" is a romantic poem where he says, "The southern breeze / from across the horizon / tells me secretly about your beauty / behind your veil" (8-11). In his poem "Dhumketu", the readers sense the Romantic temperament. Nazrul says: "I come in every age, I have come / Again for universal insurrection / I am the enemy of the Creator / I am eternal Dhumketu" (1-4).

As a matter of fact, Nazrul was a romantic poet, weather one uses the term to refer to revolt, the struggle for unity, the emphasis on emotions, imagination and beauty, or the allusions to or a focus on mysticism, incompletion, or a certain love of nature, as previously described. His poetry is burdened with the call for revolt against the "brute fact". 


\section{Treatment of Nature, Beauty and Truth}

Nazrul composed extraordinary poems on nature and love and created a sensuous world rich in colour, sound and smell. In his nature-poems, the readers find almost all the flowers available in Bengal. Dissatisfied, Nazrul makes journeys to the Middle East in search of mountains and hills, blooming flowers and singing brooks (Choudhury). In his love poem, Nazrul is sad, suffering from self-pity, and he enjoys being sad. A heavy feeling of separation hurts him continuously. He wants to dwell in some more quiet things. The silent tree, the melancholy sky, the slow moving river, the shining moon and the shy village girl are some of his oft-repeated images in his love-poetry (Choudhury). The readers find his treatment of nature in a song called "Why A Heart Longs For Another Heart" where he says "The dew knows and the flower knows / why a flower longs for the dew." (9-10)

Nazrul was also a worshipper of beauty. There are many poems and songs where he glorifies beauty. One of his songs is titled "You are beautiful, So I keep looking at you, My darling." In the song, Nazrul justifies his right to gaze at his beloved who is beautiful. Nazrul's Dolan Chapa (The Magnolia) is a collection of poems on love and beauty. In the collection, there is a poem titled "The Worshipper" where the poet adores his beloved's beauty. He says, "That voice, that dove-bewailing melody, / Those eyes, that force, That eye-brow, forehead, chin / That matchless beauty of yours" (1-4). The poet is charmed by the beauty of his beloved.

Besides, Nazrul expressed truth in many of his writings. He wrote in his poem "My Answer" that "I am only exposing / the truth in public!” (24-25) In fact, Nazrul was a defender of truth. In his "Deposition of a Political Prisoner", he declares, "The Truth reveals itself. No angry look or royal punishment can suppress it. I'm the lyre of that timeless self-revelation-the lyre in which the message of eternal Truth has been resounded" (Islam 212). To Nazrul, truth is self-evident, eternal. It cannot be destroyed by any angry-eyed scepter. So, he presented himself as the representative of 'Truth', holding the 'scepter of Justice', and expressed the truth of life through his writings.

\section{Patriotism}

Nazrul's nationalistic and patriotic songs articulated the aspirations of the subjugated class. In fact, his songs represented the common people. These celebrated unity and fraternity between Muslims and Hindus and the life struggles of the common people. His "Jogote Laglo Sara Jege Oth Uthe Dara" compiled in Jugantorer Gan (Songs of Awakening) aroused the feelings of the commoners to a high level assuring them that they are not to be subjugated by Zaminders or Lord of the Zaminders, i.e., the British any more. These feelings gave birth to revolutionary ideas in the soil of Bengal and the first man was none other than Nazrul (Abbasi 287).

Nazrul composed a number of poems and songs in jail. His "Shikal Porar Gan" (The Song on Being in Fetters) is considered as one of the greatest Bangla songs of heroic sentiment. The first stanza of the song reads, "It is our trick to be put into chains / a trick indeed / To make loose your fetters / by wearing these chains (1-4)

His "The Burning Lute" is predominantly a collection of poems of rebellious spirit. Rebellion and love are the two aspects of youthfulness. Nazrul possessed almost an inexhaustible youthful spirit. He stood for youthfulness in Bengal in those days. In rebellion and in love he expressed himself in his characteristic way.

In "Kandari Hushiar" (Beware Captain), one of the most remarkable Bangla songs of patriotic sentiment, Nazrul has made a fervent call to the captain who was here symbolically referred to mean the national leaders who would steer the ship against all odds in the age of turmoil. He referred to the Battle of Plassey and reminded everyone how the British occupation of India began and urged the leaders to move along the right track of political sojourn and strictly live up to the matter of communal amity. This song contains some immortal lines ever written by Nazrul. He writes, "Those who sang the glory of life / on the pulpit of guillotine / Have now stood unseen / what will be your sacrifice? (qtd. in Goswami, Aspects 87)

As part of the annual session of the Bengal Provincial Congress two conferences were also held. These were the Students' Conference and the Youth Conference. The students' conference opened with a song which was composed by Nazrul himself. The song was entitled "Chhatradaler Gan" (The Song of the Students). It was delivered in the form of a chorus which was led on the dais by Nazrul. The song was set to a marching musical pattern. Some lines of the lyric may be translated into English:

$$
\begin{aligned}
& \text { We are the force, we are the power } \\
& \text { We are the students. } \\
& \text { The storm swoons under our feet } \\
& \text { And the sky and cloud overhead } \\
& \text { We are the students. (1-5) }
\end{aligned}
$$

The opening song of the Youth Conference, as is largely known, was also composed by Nazrul. He composed a song titled "March Ahead". The first few lines of the song are as follows:

Forward, Forward, Forward

Drum is played in the sky overhead 
The earth is agitated below

Youths of the red dawn

Forward, Forward, Forward. (qtd. in Goswami, Aspects 91)

This is the best of Nazrul songs set to marching music and certainly is the best of Bangla songs of this kind. This marching rhythm and melody have not been very widely used in Bangla patriotic songs. It may be mentioned here that the song "Forward, forward, forward / Drum is played in the sky overhead" has been made the principal military song of Bangladesh.

Through his rebellious poems and songs, Nazrul vehemently fought against the evil forces. During the War of Independence in 1971, the patriotic and valiant freedom-fighters were motivated and rejuvenated by his rebellious poems and songs. His inspiring patriotic poems and songs speak up against all forms of oppression and misrule.

\section{Exploration of Religion}

Nazrul's Islamic and devotional songs were incorporated in the mainstream of Bangla folk music, discovering the Islamic practices of "namaz" (prayer), "roza" (fasting), "hajj" (pilgrimage) and "zakat" (charity). He composed a song titled "O Mon Ramjaner Oi Rozar Sheshe" on fasting during Ramadan. His Islamic songs are played recurrently during Ramadan in Bangladesh. This was considered by his contemporaries as a significant achievement, as Bengali Muslims had been strongly reluctant to devotional music (Azad 173-74). He also composed many reverential songs glorifying the Hindu Goddess Kali. His creativity diversified when he started composing Hindu devotional music like "shyama sangeet", "bhajans" and "kirtans". In writing these, he often blended Hindu-Muslim norms and beliefs. Nazrul's poetry and songs also projected the philosophy of Islam and Hinduism.

Nazrul's poetry depicted the passion and creativity of "Shakti", which is identified as the Brahman, the embodiment of primeval energy. He also wrote numerous songs glorifying the Lord Shiva and the goddesses Saraswati and Lakshmi, as well as the love of Krishna and Radha (Chaudhuri). His fearless attack on extremism and exploitation of women was criticized by fundamentalist Muslims, many of whom accused him as a kafir (heretic). In 1920, Nazrul expressed his notion of religious unity in an editorial in Jugobani (The Messages of Times):

Come brother Hindu! Come Musalman! Come Buddhist! Come Christian! Let us transcend all barriers, let us forsake forever all smallness, all lies, all selfishness and let us call brothers. We shall quarrel no more. (qtd. in Moniruzzaman, 149)

Nazrul not only wrote poems and songs blending Muslim and Hindu religious values, but also tried to transcend all the barriers between Muslims and Hindus. He even named his sons with both Muslim and Hindu names: Krishna Mohammad, Arindam Khaled, Kazi Sabyasachi and Kazi Aniruddha (Huda 306-307). His aim was to abolish religious narrow-mindedness and orthodoxy, and expand humanism.

\section{CONCLUSION}

Nazrul voluminously wrote between the two great wars, the great famine and communal riots occurring between the Muslims and Hindus. Through his writings, he brought about a renaissance in Muslim majority Bengal and led them into modernity. $\mathrm{He}$ was a people-oriented and revolutionary writer who all through his life protested against orthodoxy, fanaticism, religious extremism, injustice, exploitation, tyranny and all forms of inequality. As an advocate of religious harmony, he always tried to promote fraternity between the Muslims and Hindus. In his works, he promulgated the universal values of humanism, love, peace, tolerance, freedom, justice, harmony and cooperation. His poems also explored romantic love, the complete equality of men and women and attacked the social and religious malpractices of his time. So, his evaluation as a writer becomes incomplete when he is called a rebel poet of Bangla literature. It is true that Nazrul was an epoch-making rebel poet; but it is a misconception about him that he is only a rebel poet. To think in this single way is very partial in terms of assessing him and his literary works. As it has been discussed, he explored all the branches of literature that covered almost every sphere of human life. Therefore, it can be justified that Nazrul is not only a poet of rebellion but also a poet of other aspects.

\section{REFERENCES}

[1] Abbasi, Mustafa Zaman. Kazi Nazrul Islam: Man and Poet. Dhaka: Independent University Bangladesh, 2013. Print.

[2] Azad, Kamrunnesa. Dharmiya Chetonay Nazrul (Religious Consciousness in Nazrul). Dhaka: Nazrul Institute, 1999. Print.

[3] Chaudhuri, Dilip. "Nazrul Islam: The unparalleled lyricist and composer of Bengal". Press Information Bureau: Government of India. 22 Sep. 2006. Web. 02 Mar. 2020. <http://nazrul.com.bd/nazrul/works_on_nazrul/articles/chau dhuri_lyricist.htm> 
[4] Choudhury, Serajul Islam. "The Blazing Comet". New Age BD. 26 May 2006. Web. 02 Mar. 2020. < http://nazrul.com.bd/nazrul/works_on_nazrul/articles/seraju 1_comet.htm>

[5] Goswami, Karunamaya. Kazi Nazrul Islam: A Biography. Dhaka: Nazrul Institute, 2006. Print.

[6] Goswami, Karunamaya. Aspects of Nazrul Songs. Dhaka: Nazrul Institute, 1990. Print.

[7] Hawkesworth, Mary E. Globalization and Feminist Activism. USA: Rowman \& Littlefield, 2006. Print.

[8] Huda, Mohammad Nurul. "Nazrul's Personlore". Nazrul: An Evaluation. Ed. Mohammad Nurul Huda. Dhaka: Nazrul Institute, 2000. Print.

[9] Islam, Kazi Nazrul. Selected Works. Trans. Sajed Kamal. Dhaka: Nazrul Institute, 2000. Print.

[10] Langley, Winston. E. Kazi Nazrul Islam: The Voice of Poetry and the Struggle for Human Wholeness. Dhaka: Nazrul Institute, 2007. Print.

[11] Mitra, Priti Kumar. The Dissent of Kazi Nazrul Islam: Poetry and History. Dhaka: The University Press Limited, 1995. Print.

[12] Moniruzzaman, Mohammad. "Interaction of Cultures and Kazi Nazrul Islam”. Nazrul: An Evaluation. Ed. Mohammad Nurul Huda. Dhaka: Nazrul Institute, 2000. Print.

[13] Rahman, Aziz. "Nazrul: The rebel and the romantic". Daily Sun. 19 May 2017. Web. 02 Mar. 2020. < https://www.daily-sun.com/printversion/details/227418>

[14] Talukder, Tusar. "Nazrul: Preacher of freedom and love". The Asian Age. 30 May 2016. Web. 02 Mar. 2020. < https://dailyasianage.com/news/20327/nazrul-preacher-offreedom-and-love> 